\title{
Serum Erythropoietin and Erythropoiesis in Primary and Secondary Hyperparathyroidism : Effect of Parathyroidectomy
}

\author{
Pablo Ureña ${ }^{\mathrm{a}}$, Kai-Uwe Eckardt ${ }^{\mathrm{b}}$. Emile Sarfati ${ }^{\mathrm{c}}$, Johanna Zingraff ${ }^{\mathrm{a}}$. Brigitte Zins ${ }^{\mathrm{a}}$. Jean Baptiste Roullet ${ }^{\mathrm{a}}$. \\ Eric Roland ${ }^{\mathrm{c}}$. Tilman Drüeke ${ }^{\mathrm{a}}$, Armin Kurtz ${ }^{\mathrm{b}}$ \\ a Département de Néphrologie, INSERM U90, Hôpital Necker-Enfants Malades, Paris. France: \\ ${ }^{b}$ Physiologisches Institut der Universität Zürich, Switzerland: \\ 'Service de Chirurgie Viscérale, Hôpital Saint Louis, Paris, France
}

Key Words. Erythropoietin · Uremia · Hemodialysis · Anemia · Hyperparathyroidism - Parathyroidectomy . Calcitriol

Abstract. Primary as well as secondary hyperparathyroidism may be associated with anemia, and parathyroidectomy (PTx) may improve or even heal it. The precise link between the two conditions is still matter of dicussion. The purpose of the present study was to investigate possible effects of PTx on serum immunoreactive erythropoietin (iEPO) in secondary (group $I, n=23$ ), and primary (group $I I, n=16$ ) hyperparathyroidism patients, and in 3 patients undergoing cervicotomy for thyroid mass removal (group III). In group I patients, circulating iEPO levels rose from $23.1 \pm 4.8 \mathrm{mU} / \mathrm{ml}$ before PTx to $28.2 \pm 5.0$ and $245 \pm 125 \mathrm{mU} / \mathrm{ml}($ mean $\pm \mathrm{SEM})$ at day $7(\mathrm{p}=\mathrm{NS})$ and 14 after PTx $(\mathrm{p}<0.003)$, respectively. Reticulocyte count increased 2 weeks after PTx: from $61,000 \pm 13,317$ to $86,533 \pm 13,462 / \mathrm{mm}^{3}$ $(\mathrm{p}<0.05, \mathrm{n}=23)$. In 4 of these patients serum iEPO levels could be measured again $12-24$ months after PTx. They were slightly higher than those determined before PTx: $37.0 \pm 8.4$ versus $31.8 \pm 13.5 \mathrm{mU} / \mathrm{ml}$. Their hematocrits were also higher than before PTx: $12.8 \pm 0.9$ versus $11.0 \pm 0.9 \mathrm{~g} / \mathrm{dl}$. In group II patients, serum iEPO levels remained unchanged after PTx: $17.5 \pm 2.0 \mathrm{mU} / \mathrm{ml}$ before PTx and $20.0 \pm 3.0 \mathrm{mU} / \mathrm{ml} 14$ days after PTx. The reticulocyte count, however, increased significantly 2 weeks after PTx: from $25,103 \pm 3,000$ to $40,827 \pm 4,080 / \mathrm{mm}^{3}(\mathrm{p}<0.01)$. In group III patients, serum iEPO, reticulocyte count, and hemoglobin remained stable after surgery. Since all group I patients had received vitamin D supplementation after PTx, we studied an additional group of 14 chronic dialysis patients (group IV) who received either calcitriol $(1 \mu \mathrm{g} /$ day, $n=7)$ or placebo $(n=7)$ during 14 days. The patients on calcitriol treatment, but not those on placebo, had a significant decrease of serum iEPO: $18.6 \pm 4.9$ versus $16.0 \pm 4.2 \mathrm{mU} / \mathrm{ml}(\mathrm{p}<0.03)$. In conclusion, PTx led to a striking increase of serum iEPO and blood reticulocytes in uremic patients with secondary hyperparathyroidism, and an increase of reticulocyte count, but not of iEPO, in patients with primary hyperparathyroidism. Marked changes of circulating PTH, extra- or intracellular calcium and phosphorus concentrations as well as of tissue sensitivity to EPO after PTx could all be responsible. In contrast, the surgical procedure and the therapeutic increase in plasma calcitriol do not appear to be involved.

\section{Introduction}

Erythropoietin (EPO) is a circulating glycoprotein with a molecular weight of approximately 34,000 daltons [1-3] which after neonatal life is produced by peritubular endothelial or interstitial cells in the cortex and outer medulla of the kidney [4-6]. Its principal effect is to stimulate red cell proliferation and differentiation in the bone marrow. Its production and secretion are regulated by the ambient oxygen pressure. Evidence indicates that it is the supply of and demand for oxygen by kidney cells that determines EPO production [7], and in addition, it 
has recently been demonstrated using molecular biology methods that tissue hypoxia stimulates the renal EPO mRNA [8]. However, the mechanisms by which renal oxygen supply determines the amount of EPO mRNA are still unknown.

Anemia of moderate to severe degree is a feature complicating almost invariably chronic renal failure (CRF). Its pathophysiology is multifactorial. Several possible mechanisms have been described [9]: (1) decreased EPO production; (2) shortened red cell survival; (3) retained inhibitors or toxic substances that interfere with erythroid marrow function; (4) iron and folate deficiency, and (5) blood loss. However, the most important cause of the anemia of end-stage renal disease is clearly EPO deficiency.

With the recent development of radioimmunoassay techniques using antibodies directed against recombinant human EPO (r-HuEPO) precise measurements of serum EPO levels have become posible. They show that levels in patients with CRF may be within the range of normal, low or high [10]. Relative EPO deficiency is clearly present in most of the uremic patients who fail to display an appropriate compensatory erythropoietic response to their anemia. The recent introduction of $r$-HuEPO into clinical use has allowed to correct effectively the anemia of uremic patients on intermittent hemodialysis treatment [11-13].

Besides the above-mentioned mechanisms including inappropriate EPO production, secondary hyperparathyroidism has also been considered as a possible cause in the development of anemia during CRF [14-17]. This consideration results from observations that primary hyperparathyroidism is sometimes associated with anemia $[18,19]$. Conversely, surgical ablation of parathyroid adenoma has been shown to correct the anemia observed during primary hyperparathyroidism $[18,19]$ and to improve the anemia in about $50 \%$ of parathyroidectomized patients with CRF [20-22]. The way by which hyperparathyroidism worsens and parathyroidectomy (PTx) improves renal anemia is not well understood. It could involve a direct inhibitory effect parathyroid hormone (PTH) on erythropoiesis or the induction of marrow fibrosis. A possible interference with EPO production has so far not been considered.

It seemed reasonable therefore to determine the kinetics of serum EPO levels in primary and secondary hyperparathyroidism after PTx as well as the other main hematological parameters. Moreover, we have examined a possible effect of calcitriol treatment on serum EPO levels in uremic hemodialysis patients.

\section{Patients and Methods}

\section{Patients}

Group I. Twenty chronically uremic patients undergoing maintenance hemodialysis, I patient on chronic ambulatory peritoneal dialysis, and 2 patients with advanced $C R F(C \mathrm{cr}<10 \mathrm{ml} / \mathrm{min})$ not yet on dialysis were referred to our center for the indication of surgical correction of severe secondary hyperparathyroidism. Their mean age was $50.7 \pm 3.3$ years $( \pm S E M)$. Eleven out of the 23 patients were females and 12 males. Mean duration of hemodialysis treatment was $8.0 \pm 1.0$ years. The etiology of renal disease was renal vascular disease in 3 patients, glomerulonephritis in 5, polycystic kidney disease in 5 . chronic interstitial nephropathy in 6 , renal cortical necrosis in 1 and unknown in 3 . Because of severe secondary hyperparathyroidism PTx was indicated for all patients, based on clinical, biochemical, radiological, and histological (bone biopsy) criteria and failure of previous medical therapy. Subtotal PTx (ablation of $3 \mathrm{glands}$ and of $1 / 3$ to $2 / 3$ of the 4 th) was performed in 10 patients and total PTx followed by immediate autografting of several parathyroid fragments into the forearm brachioradialis muscle in the other 13 patients. All parathyroid glands were identified histologically on frozen section before excision. Following PTx, calcium $\left(\mathrm{CaCO}_{3}\right)$ and vitamin $\mathrm{D}$ ( $1 \alpha \mathrm{OH}$ vitamin $\left.\mathrm{D}_{3}\right)$ supplementation was required by all patients to bring plasma tota! calcium concentration back to levels above $2.0 \mathrm{mmol} / 1$. Dialysis patients were treated during their hospital stay by conventional bicarbonate hemodialysis $(4-5 \mathrm{~h}$ thrice weekly). The dialysate calcium concentration was 1.75 $\mathrm{mmol} / \mathrm{l}$.

Seven patients with severe symptomatic anemia (hematocrit between 16 and $30^{\circ}$ ) required blood transfusions before operation to maintain hematocrit at about $30-35 \%$. None of the patients suffered from sickle cell anemia or myeloproliferative disease. None of the patients received antianemic treatment such as vitamins, ferrous salt, androgen or $r$-HuEPO. The duration of follow-up in the hospital was 3 weeks for each patient, 1 week before and 2 weeks after PTx.

Group II. Sixteen subjects with normal renal function were referred for surgical correction of primary hyperparathyroidism. Their mean age was $62.8 \pm 4.6$ years. Ten out of the 16 patients were females and 6 males. Subtotal PTx (ablation of an adenoma) was performed in all patients. Parathyroid adenomas were identified histologically on frozen section before excision. Following PTx, calcium $\left(\mathrm{CaCO}_{3}\right)$ and vitamin $\mathrm{D}\left(1 \alpha \mathrm{OH}\right.$ vitamin $\left.\mathrm{D}_{3}\right)$ supplementation was required only by some patients to maintain plasma total calcium concentration above $2.0 \mathrm{mmol} / \mathrm{l}$. All the patients were followed during 2 weeks after PTx.

Group III. Three subjects (1 female, 2 males) with normal renal function were referred for surgical correction of a thyroid mass. Their mean age was $59.8 \pm 9.1$ years. Cervicotomy was followed by ablation of a thyroid nodule in all patients. Calcium or vitamin D supplementation was not required. The three patients were followed during 2 weeks after the cervical surgery.

Group IV. Fourteen chronically uremic patients undergoing maintenance hemodialysis were studied in order to investigate the influence of calcitriol on EPO kinetics. They had a mean age of $43.9 \pm 3.7$ years. Half of the patients were females and the other half males. This group was subdivided in a random fashion into two groups of 7 patients each (groups A and B). Oral treatment with the active vitamin D metabolite, calcitriol (1 $4 \mathrm{~g} /$ day during 14 days) was 
administered to half of the patients (group A). Simultaneously, the other half (group B) patients received a placebo. Group A patients had a mean age of $39.0 \pm 5.18$ years. They were 3 females and 4 males. Mean duration of hemodialysis treatment was $4.3 \pm 2.4$ years. The etiology of renal disease comprised glomerulonephritis ( $5 \mathrm{pa}$ tients) and hereditary nephropathy ( 2 patient). Group B patients had a mean age of $48.9 \pm 4.8$ years. They were 4 females and 3 males. Mean duration of hemodialysis treatment was $1.4 \pm 0.5$ years. The etiology of renal disease comprised glomerulonephritis (2 patients), polycystic kidney disease (1 patient), interstitial nephropathy (3 patients) and unknown ( 1 patient). None of the patients received oral vitamin D supplementation during the month prior to study. Patients were treated by conventional acetate or bicarbonate hemodialysis (4-5 h thrice weekly). The dialysate calcium concentration was $1.75 \mathrm{mmol} / \mathrm{l}$. None of the patients required blood transfusions during the study. None of the patients suffered from another type of anemia, inflammatory disorders or myeloproliferative diseases. None of the patients received antianemic treatment such as folic acid, ferrous salt, androgen or r-HuEPO.

All the patients gave their informed consent to participate in these studies.

\section{Hematological Parameters}

Blood sampling was always performed after a 12-hour fast. before a hemodialysis session in uremic patients undergoing hemodialysis treatment. Blood hemoglobin $(\mathrm{Hb})$, packed cell volume (PCV), platelets, reticulocytes and serum immunoreactive EPO (iEPO) concentration were measured during the week before and 2 times after cervicotomy (day 7 and 14) in all patients of groups I. II and III. Serum iEPO concentration was again measured 12-24 months after PTx in 4 group 1 patients. Group IV patients had only two blood samples for the determination of serum iEPO, namely before and at the end of calcitriol or placebo administration (day 0 and 14).

\section{Biochemical Parameters}

Plasma total calcium and phosphorus levels were measured during the week before PTx and at least 2 times after cervicotomy (day 7 and 14) in all patients of groups I, II, and III. In group IV patients they were measured during the week before calcitriol or placebo treatment and thrice a week thereafter until the end of study. Plasma immunoreactive PTH (iPTH) was measured before and 14 days after the surgery in the three first groups of patients. Basal plasma aluminum, was measured in all 23 patients of group I. and plasma $\mathrm{Al}$ after deferoxamine (DFO) infusion in 22 group I patients. Plasma Al after DFO (1-hour infusion of DFO of $40 \mathrm{mg} / \mathrm{kg}$ body weight was determined at 2, 4, 8, 24, and $48 \mathrm{~h}$ after start of infusicn.

Plasma calcium was determined using atomic absorption spectrometry, plasma phosphorus using a Technicon Auto Analyzer. Plasma Al was determined using atomic absorption spectrometry with a graphite oven, and plasma iPTH using an antibody directed against the entire PTH molecule (normal values: $10-65 \mathrm{pg} / \mathrm{ml}$ ).

Serum iEPO concentrations were determined by radioimmunoassay as described elsewhere [23]. Normal values in healthy adults with this assay are comprised between 11 and $31 \mathrm{mU} / \mathrm{ml}$ ( $95 \%$ confidence interval: mean, $17.9 \mathrm{mU} / \mathrm{ml}, \mathrm{n}=84$ ). Two samples containing more than $100 \mathrm{mU} \mathrm{ml}$ iEPO were also assayed in the polycythemic mouse assay for EPO, exactly as described previously [23].

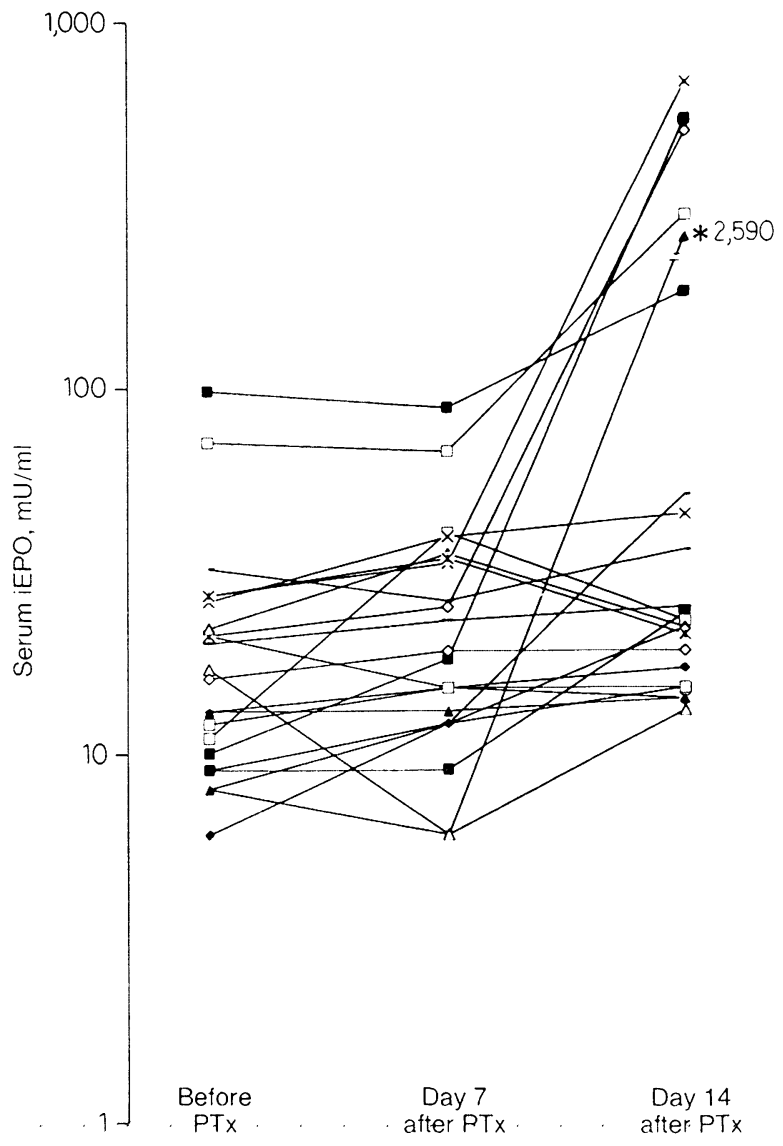

Fig. 1. Serum iEPO before and at day 7 and at day 14 after PTx in 22 hemodialysis patients is shown.

\section{Statistical Analysis}

All results are given as the mean \pm SEM. Statistical analysis was performed using one-way analysis of variance, paired or unpaired Student's test or Mann-Whitney U test as appropriate. The significance of the magnitude of correlation coefficients between biochemical values was assessed by linear regression analysis.

\section{Results}

\section{Hematological Parameters}

Patients of group I had a marked increase of serum iEPO concentration after PTx. Mean circulating iEPO before PTx (1-7 days) was $23.1 \pm 4.8 \mathrm{mU} / \mathrm{ml}(\mathrm{n}=23)$. The highest $(71 \mathrm{mU} / \mathrm{ml})$ and lowest $(6 \mathrm{mU} / \mathrm{ml})$ values were observed in 2 patients with hypertensive nephropathy. At day 7 and 14 after PTx, mean serum iEPO concentration was $28.2 \pm 5.0$ and $245 \pm 125 \mathrm{mU} / \mathrm{ml}$, respectively (fig. 1). The difference between pre-PTx and post-PTx values at day 14 was highly significant $(p<0.003$, table 1$)$. It must 
Table 1. Effect of PTx and ablation of a thyroid nodule on serum iEPO levels $(\mathrm{mU} / \mathrm{ml})$

\begin{tabular}{llll}
\hline & $\begin{array}{l}\text { Before } \\
\text { surgery }\end{array}$ & $\begin{array}{l}7 \text { days after } \\
\text { surgery }\end{array}$ & $\begin{array}{l}14 \text { days after } \\
\text { surgery }\end{array}$ \\
\hline $\begin{array}{l}\text { Group I } \\
\text { (secondary } \\
\text { hyperparathyroidism) }\end{array}$ & $\begin{array}{l}23.1 \pm 4.8 \\
(\mathrm{n}=23)\end{array}$ & $\begin{array}{l}28.2 \pm 5.0 \\
(\mathrm{n}=23)\end{array}$ & $\begin{array}{l}245 \pm 125^{*} \\
(\mathrm{n}=23)\end{array}$ \\
\hline $\begin{array}{l}\text { Group II } \\
\text { (primary }\end{array}$ & $\begin{array}{l}17.5 \pm 2.0 \\
(\mathrm{n}=16)\end{array}$ & $\begin{array}{l}20.0 \pm 3.0 \\
(\mathrm{n}=16)\end{array}$ \\
$\quad \begin{array}{lll}\text { hyperparathyroidism) } \\
\text { Group III } \\
\quad \text { (subtotal }\end{array}$ & $16.0 \pm 1.2$ & $\begin{array}{l}20.3 \pm 1.8 \\
(\mathrm{n}=3)\end{array}$ & $\begin{array}{l}19.0 \pm 2.0 \\
(\mathrm{n}=3)\end{array}$ \\
\hline thyroidectomy) & $(\mathrm{n}=3)$ & $(\mathrm{n}=3)$ &
\end{tabular}

Values are means \pm SEM. ${ }^{*} \mathrm{p}<0.003$
Table 2. Effect of PTx and ablation of a thyroid nodule, on reticulocyte count per $\mathrm{mm}^{3}$ of whole blood

\begin{tabular}{lll}
\hline & $\begin{array}{l}\text { Before } \\
\text { surgery }\end{array}$ & $\begin{array}{l}14 \text { days after } \\
\text { surgery }\end{array}$ \\
\hline $\begin{array}{l}\text { Group I } \\
\text { (secondary } \\
\text { hyperparathyroidism) }\end{array}$ & $\begin{array}{l}61,000 \pm 13,317 \\
(\mathrm{n}=23)\end{array}$ & $\begin{array}{l}86,533 \pm 13,462^{*} \\
(\mathrm{n}=23)\end{array}$ \\
$\begin{array}{l}\text { Group II } \\
\text { (primary } \\
\text { hyperparathyroidism) }\end{array}$ & $\begin{array}{l}25,103 \pm 3,000 \\
(\mathrm{n}=16)\end{array}$ & $\begin{array}{l}40,827 \pm 4.080^{* *} \\
(\mathrm{n}=16)\end{array}$ \\
\hline $\begin{array}{l}\text { Group III } \\
\text { (subtotal } \\
\text { thyroidectomy) }\end{array}$ & $\begin{array}{l}44,663 \pm 17,868 \\
(\mathrm{n}=3)\end{array}$ & $\begin{array}{l}38,205 \pm 23,366 \\
(\mathrm{n}=3)\end{array}$ \\
\hline
\end{tabular}

Values are means \pm SEM. ${ }^{*} \mathrm{p}<0.05 ;{ }^{*} \mathrm{p}<0.01$

Table 3. Long-term follow-up of $\mathrm{Hb}$ and serum iEPO after PTx in 4 uremic hemodialysis patients

\begin{tabular}{llllll}
\hline & Before surgery & 1 week after PTx & 2 weeks after PTx & 1 year after PTx & 2 years after PTx \\
\hline Hemoglobin, g \% & $11.0 \pm 0.9$ & $10.4 \pm 0.6$ & $9.7 \pm 0.9$ & $12.0 \pm 0.8$ & $12.8 \pm 0.9$ \\
\hline $\mathrm{iEPO}, \mathrm{mU} / \mathrm{ml}$ & $31.8 \pm 13.5$ & $33.3 \pm 12.8$ & $382 \pm 135$ & $40.6 \pm 12.8$ & $37.0 \pm 8.4$ \\
\hline
\end{tabular}

Values are means \pm SEM.

also be noted that the greatest increases in serum iEPO concentration 14 days after PTx have been observed only in those patients who did not receive a blood transfusion after surgery. Eighteen out of the 23 patients presented a serum $\mathrm{iEPO}$ increase. In addition, we have measured serum $\mathrm{iEPO}$ levels and $\mathrm{Hb}$ again in 4 group I patients 12 and 24 months after PTx. Mean serum iEPO values were slightly higher than that determined before PTx: $37.0 \pm 8.4$ versus $31.8 \pm 13.5 \mathrm{mU} / \mathrm{ml}$. These 4 patients showed a marked increase of $\mathrm{Hb} 2$ years after PTx, and none of the patients had received blood transfusion during this period: from $11.0 \pm 0.9$ to $12.8 \pm 0.9 \mathrm{~g} / \mathrm{dl}$ (table 2). Another patient required intermittent phlebotomy due to polycythemia 6 months after PTx. In 2 patients with more than $100 \mathrm{mU} / \mathrm{ml}$ iEPO 14 days after PTx, serum was also assayed in the polycythemic mouse assay for EPO. These measurements confirmed the results obtained by radioimmunoassay, thus indicating that circulating $\mathrm{iEPO}$ material contained full bioactivity $(1,635 \pm 789$ vs. $1,750 \pm 413 \mathrm{mU} / \mathrm{ml})$.

There was no significant difference between mean PCV and mean Hb values before and 14 days after PTx in group I patients. Mean PCV was $27.4 \pm 2.2 \%$ before PTx, $28.8 \pm 1.4 \%$ at day 7 , and $27.2 \pm 1.5 \%$ at day 14 after PTx, respectively. Mean $\mathrm{Hb}$ values were $9.2 \pm 0.7 \mathrm{~g} / \mathrm{dl}$ before
PTx, $9.7 \pm 0.4 \mathrm{~g} / \mathrm{dl}$ at day 7 , and $9.2 \pm 0.5 \mathrm{~g} / \mathrm{dl}$ at day 14 after PTx, respectively. All the patients had anemia (PCV $<30 \%$ ), only 1 patient had a PCV $>30 \%$. A modest, but significant increase in reticulocyte count was observed at day 14 after PTx from $61,000 \pm 13,317$ to $86,533 \pm 13,462 / \mathrm{mm}^{3}(\mathrm{p}<0.05, \mathrm{n}=23$, table 3$)$.

Figure 2 shows the follow-up of serum iEPO, reticulocyte count, $\mathrm{Hb}$, and plasma iPTH after PTx in a representative patient. The marked decrease of plasma iPTH immediately after PTx was associated with a parallel increase of serum iEPO and reticulocyte count. Figure 3 depicts the follow-up of the same parameters in an other patient who had only a partially effective PTx. The progressive decrease of plasma iPTH was consistent but it was much slower compared with the patient of figure 2 . The degree of the decrease of plasma iPTH and phosphorus concentration correlated with the increase of serum iEPO and reticulocyte count.

An increase in platelet count was observed after PTx in all patients of group I, which was statistically significant from 7-day onwards: $204,250 \pm 22,294 / \mathrm{mm}^{3}$ before PTx, $223,100 \pm 23,178 / \mathrm{mm}^{3}$ at day 7 after PTx and $256,727 \pm 40,320 / \mathrm{mm}^{3}$ at day 14 after PTx, respectively $(p<0.03$ and $p<0.006$, respectively, $n=23$ ). 

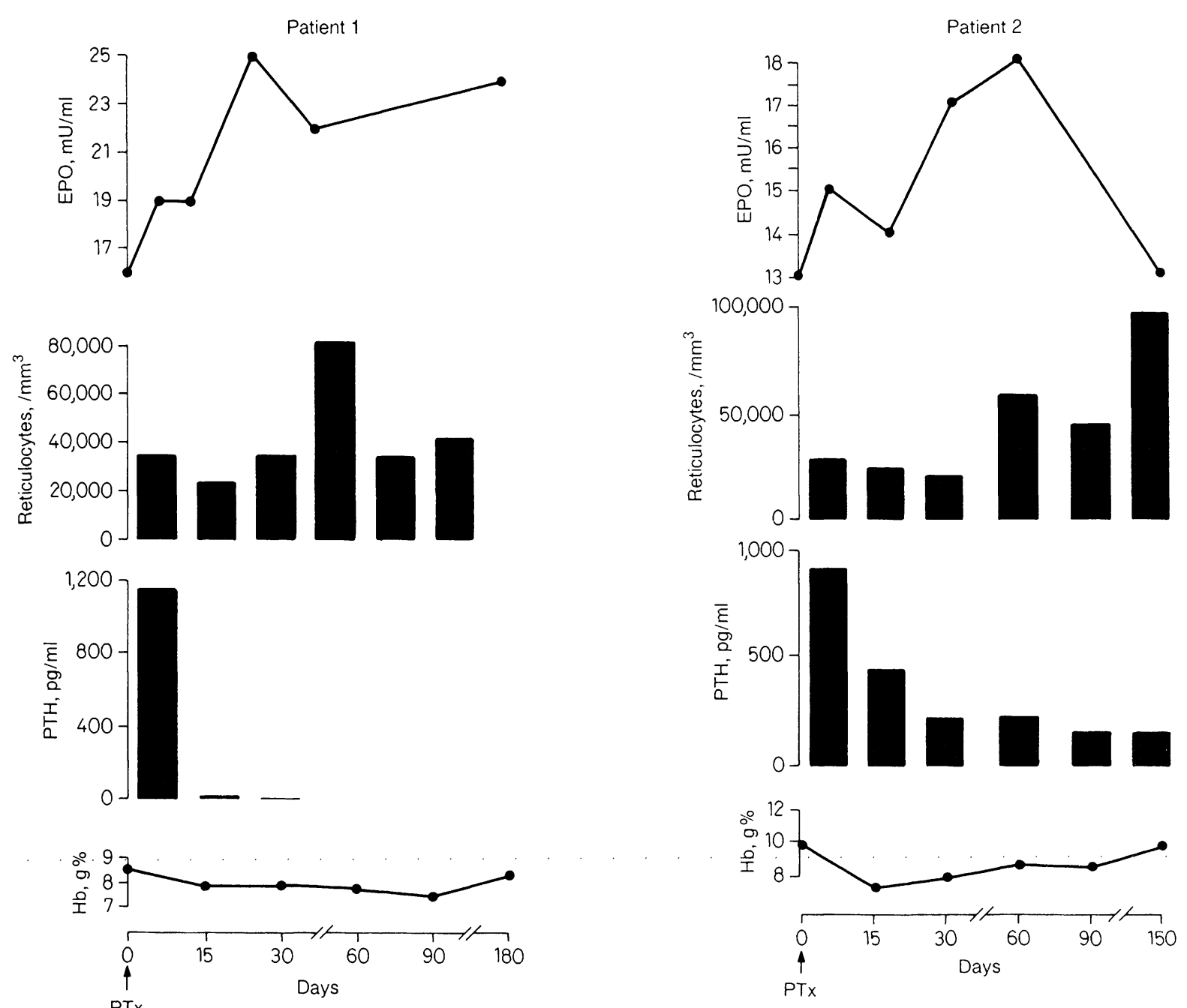

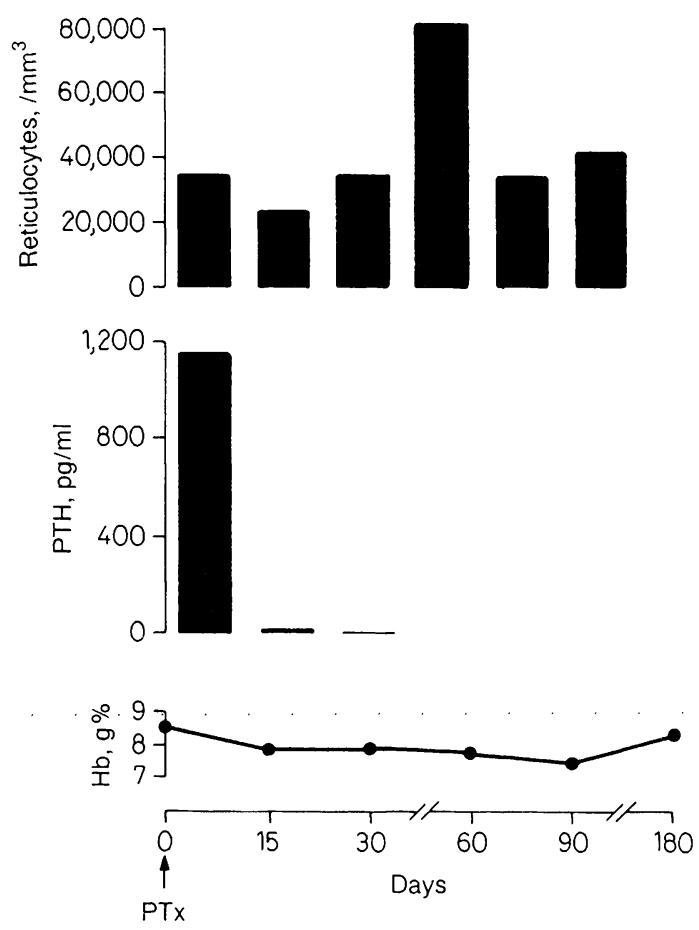

Fig. 2. Follow-up of serum iEPO, reticulocyte count, plasma iPTH, and $\mathrm{Hl}$ after PTx in a patient who had a rapidly efficacious PTx.

Group II patients operated for primary hyperparathyroidism had a modest, but not significant, increase of serum iEPO concentration 14 days after PTx: $17.5 \pm 2.0$ versus $20.0 \pm 3.0 \mathrm{mU} / \mathrm{ml}(\mathrm{n}=16, \mathrm{p}=\mathrm{NS}$, table 1$)$. Mean $\mathrm{PCV}$ and mean $\mathrm{Hb}$ values did not change significantly after PTx. Mean PCV was $38.2 \pm 3.5 \%$ before PTx, $35.9 \pm 5.4 \%$ at day 7 , and $36.8 \pm 4.5 \%$ at day 14 after PTx, respectively. Mean $\mathrm{Hb}$ values were $13.0 \pm 1.3 \mathrm{~g} / \mathrm{dl}$ before PTx, $12.6 \pm 1.4$ $\mathrm{g} / \mathrm{dl}$ at day 7 , and $12.4 \pm 1.4 \mathrm{~g} / \mathrm{dl}$ at day 14 after PTx, respectively. Twenty-five percent, that is 4 out of 16 patients, in this group had an anemia $(\mathrm{PCV}<35 \%)$. A significant increase in reticulocyte count was apparent 2 weeks after PTx: from $25,103 \pm 3,000 / \mathrm{mm}^{3}$ to $40,827 \pm 4,080 / \mathrm{mm}^{3}$ $(\mathrm{p}<0.01, \mathrm{n}=16$, table 3$)$. There was also an increase in platelet count after PTx: from $274,440 \pm 20,280 / \mathrm{mm}^{3}$ be-
Fig. 3. Follow-up of serum iEPO, reticulocyte count, plasma iPTH, and $\mathrm{Hb}$ after PTx in another patient who had an only partially efficacious PTx.

fore PTx to $279,940 \pm 67,290$ at day 7 and to $310,940 \pm 71,860$ at day 14 after PTx, respectively $(\mathrm{p}<0.07, \mathrm{n}=16)$.

Group III patients, operated upon for a thyroid mass, had no apparent perturbation of calcium metabolism. Similary to primary hyperparathyroidism patients, they had no increase of serum iEPO concentration 14 days after PTx: $16.0 \pm 1.2$ versus $19.0 \pm 2.0 \mathrm{mU} / \mathrm{ml}(\mathrm{n}=3$, table 1). Mean PCV and mean $\mathrm{Hb}$ values did also not change after PTx: mean PCV was $39.2 \pm 3.5 \%$ before PTx, $37.6 \pm 2.3 \%$ at day 7 , and $37.4 \pm 2.4 \%$ at day 14 after PTx, respectively, and mean $\mathrm{Hb}$ values $13.0 \pm 1.4 \mathrm{~g} / \mathrm{dl}$ before PTx, $12.4 \pm 1.0 \mathrm{~g} / \mathrm{dl}$ at day 7 , and $12.3 \pm 1.0 \mathrm{~g} / \mathrm{dl}$ at day 14 after PTx, respectively. Reticulocyte count did also not change 2 weeks after PTx, 44,663 $\pm 17,868$ rersus $38,205 \pm 23,366 / \mathrm{mm}^{3}$ (table 3 ). There was a slight increase 


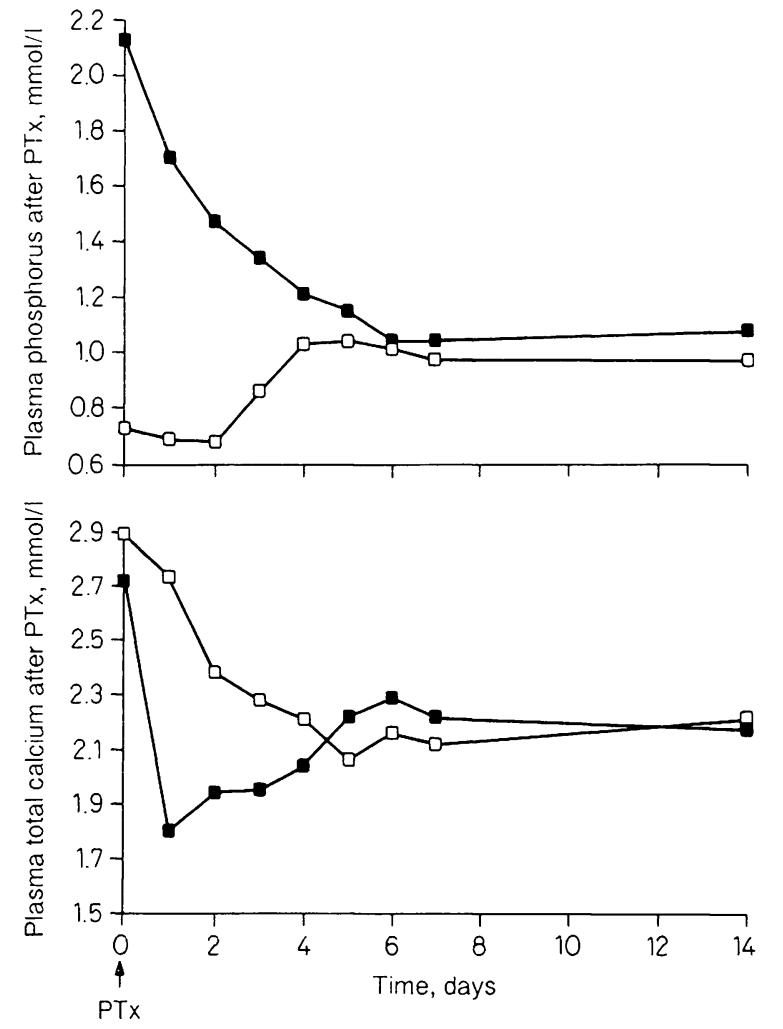

Fig. 4. a Follow-up after PTx of mean plasma phosphate of patients with primary hyperparathyroidism $(\square)$ and secondary hyperparathyroidism (ם). b Follow-up of mean plasma total calcium after PTx in the same groups of patients.

in platelet count after PTx: from $255,330 \pm 122,320 / \mathrm{mm}^{3}$ before PTx to $277,000 \pm 151,000 / \mathrm{mm}^{3}$ at day 7 , and to $280,000 \pm 95,390 / \mathrm{mm}^{3}$ at day 14 after PTx, respectively.

Patients of group IV had a slight, but statistically significant decrease of serum iEPO after calcitriol therapy (group A): from $18.6 \pm 4.9$ to $16.0 \pm 4.2 \mathrm{mU} / \mathrm{ml}(\mathrm{n}=7$, $\mathrm{p}<0.03)$. In group IV patients who received placebo (group B) no difference was found between mean serum iEPO before as compared to after placebo intake: $11.4 \pm 1.4$ versus $12.0 \pm 2.1 \mathrm{mU} / \mathrm{ml}$. No significant difference of serum iEPO concentration existed between groups $\mathrm{A}$ and $\mathrm{B}$ at the start of study. There was no significant difference between mean PCV and mean $\mathrm{Hb}$ values before and after calcitriol therapy in both groups.

\section{Plasma Biochemistry}

Figure 4 shows the follow-up of plasma phosphate for group I and group II of patients after PTx. In secondary hyperparathyroidism (group I), mean plasma phosphate before PTx was $2.17 \pm 0.15 \mathrm{mmol} / \mathrm{l}$. It decreased to $0.82 \pm 0.10 \mathrm{mmol} / 1$ immediately after PTx $(p<0.001$, $\mathrm{n}=23$ ). By contrast, in primary hyperparathyroidism (group II), mean plasma phosphate before PTx was $0.73 \pm 0.04 \mathrm{mmol} / \mathrm{l}$, and it increased to $0.97 \pm 0.062$ weeks after PTx $(p<0.01, n=16)$. Figure 3 also depicts the course of mean plasma total calcium in both groups of patients. In group I, pre-PTx mean plasma total calcium was $2.78 \pm 0.05 \mathrm{mmol} / \mathrm{l}$. It decreased to $1.80 \pm 0.06$ $\mathrm{mmol} / \mathrm{l}$ immediately after PTx. By contrast, in group II pre-PTx mean plasma total calcium was $2.89 \pm 0.04$ $\mathrm{mmol} / \mathrm{l}$. It decreased to $2.06 \pm 0.14 \mathrm{mmol} / 15$ days after PTx. The former patients required high doses of calcium carbonate to maintain the calcemia above $2.00 \mathrm{mmol} / 1$ whereas group II patients did not.

Group I patients had a mean pre-PTx plasma iPTH concentration of $906 \pm 68 \mathrm{pg} / \mathrm{ml}$. It decreased to $120 \pm 17$ $\mathrm{pg} / \mathrm{ml} 2$ weeks after PTx. Group II patients had a mean pre-PTx plasma iPTH concentration of $148 \pm 89 \mathrm{pg} / \mathrm{ml}$. It decreased to $37 \pm 312$ weeks after PTx. Group I patients had significantly higher pre-PTx plasma iPTH levels than group II patients as well as a higher degree of plasma iPTH decrease after PTx. In group III plasma iPTH did not change after surgery: $45 \pm 22$ versus $38 \pm 17 \mathrm{pg} / \mathrm{ml}$.

In group I patients, basal plasma $\mathrm{Al}$ concentration before PTx was $2.02 \pm 0.25 \mu \mathrm{mol} / 1(\mathrm{n}=22)$.

Amongst group IV patients, group A had a significant increase of plasma total calcium and phosphorus at day 15 after calcitriol administration: $2.34 \pm 0.02$ and $1.58 \pm 0.17 \mathrm{mmol} / \mathrm{l}$ before treatment versus $2.50 \pm 0.07$ and $2.00 \pm 0.26 \mathrm{mmol} / 1$ at day $15(\mathrm{p}<0.01$ and $\mathrm{p}<0.03$, respectively, $n=7$ ). No such increase of plasma total calcium or plasma phosphorus was observed in group B patients.

\section{Correlations}

We tried to establish correlations between several plasma parameters in group I and group II patients. In either group, no relation was found between plasma total calcium, plasma phosphorus, and plasma iPTH before PTx and serum iEPO levels before PTx. In the two groups of patients, we were also unable to observe a relation between the maximum decrease in plasma total calcium after PTx and serum iEPO levels before or after PTX. Moreover, the decrease in plasma phosphorus after PTx in group I patients was not related to the increase in serum $\mathrm{iEPO}$, and the increase in plasma phosphorus after PTx in group II patients was not related to serum iEPO after PTx. There was no relation between basal plasma Al or the delta of $\mathrm{Al}$ increase after DFO infusion and serum iEPO before or after PTx in group I patients. In patients of group I no relation was found between serum iEPO 
levels and PCV before or after PTx. By contrast, in group II patients in whom this relation was also absent before PTx, a significant negative relation was found 2 weeks after PTx $(\mathrm{p}<0.003)$. No relation could be detected between serum iEPO and blood reticulocytes or between the increase in serum iEPO and the change in circulating reticulocytes.

\section{Discussion}

This study demonstrates the novel finding of a striking, significant increase in serum iEPO concentration immediately after the surgical correction of severe secondary hyperparathyroidism in chronic hemodialysis patients. Such an increase was not observed after the surgical correction of primary hyperparathyroidism or after cervicotomy for thyroid surgery. In an additional study, we found a slight, but significant, decrease of circulating iEPO after a 14-day, high-dose calcitriol treatment in dialysis patients which was not observed in patients receiving placebo.

Prior to the surgical intervention, serum iEPO levels in the uremic patients undergoing hemodialysis and in patients with primary hyperparathyroidism were inappropriately low in relation to hematocrit values. No correlation existed between serum iEPO levels and hematocrit values before PTx. This observation has already been made by other authors [24-26] in the condition of secondary hyperparathyroidism. We found that this was also true for patients with primary hyperparathyroidism. After surgical correction of primary hyperparathyroidism serum iEPO increased slightly, but not significantly. However, a relationship between EPO and hematocrit became then apparent.

Hyperparathyroidism may contribute to renal anemia either by a direct inhibitory effect on erythropoiesis or through osteitis fibrosa or both. Evidence of an improvement of anemia has been obtained in several dialysis patients after PTx [20-22] as well as after PTx in patients with primary hyperparathyroidism [17, 18]. In uremic patients, the improvement of the anemia after PTx was associated with a regression of marrow fibrosis [20], lowering of the serum phosphate level [27], and a decrease of plasma iPTH [14, 19]. However, a direct relation between plasma iPTH levels and the degree of anemia or inhibition of erythropoiesis could never be demonstrated [20, 28, 29].

As to serum iEPO concentration, it has been found to slightly increase 9-12 months after PTx in one study [29].
The present short-term study in the majority of uremic patients was not aimed at confirming the improvement of anemia which we have shown to occur after PTx in a previous study in hemodialysis patients [20]. Interestingly, it shows a marked increase of serum iEPO after PTX. Since it is the bioavailability of EPO that is the limiting factor for erythropoiesis during CRF, the increase of serum iEPO after PTx could account for the improvement of anemia in uremic patients. Presently, we do not know how long the rise of serum iEPO lasts after PTx. Data obtained from 4 patients suggests that 1-2 years after PTx, serum iEPO levels have more or less declined to the preoperative values.

More interestingly, our findings indicate that the uremic organism is in principle capable of producing EPO in amounts that should be sufficient to compensate the anemia. This finding is in accordance with a recent observation which states that acute hypoxia elicits up to 10 -fold increases of serum EPO levels in severely anemic children with CRF [25]. However, the time course of the increase in serum iEPO levels was different between these uremic children and our dialysis patients, in that the increase was less marked and more rapid in the children and that iEPO values returned to lower levels already 24-28 h after hypoxic stress.

In our study we did not obtain evidence for the source of EPO nor for the mechanism by which PTx could elevate serum EPO levels. Several mechanisms can be considered. The possibility that the rise of serum iEPO is an unspecific side effect of the surgical intervention is unlikely for at least two reasons. Firstly, two control groups, namely, 2 patients who received abdominal surgery [30], and 3 patients of ours who underwent cervicotomy for thyroid mass, failed to increase serum iEPO after surgery. It is also of note that blood gases did not change following PTx. Secondly, the data on serum iEPO levels obtained after renal allotransplantation by others [31] and ourselves [32] also suggest that surgery has no effect per se on serum EPO levels. It is the lag time and the amplitude of the increase of serum EPO levels that are significantly different between renal transplantation and PTx.

Blood loss during surgery could have constituted the main stimulus for EPO production. Walle et al. [26] showed that only a $58 \%$ rise in serum iEPO levels occurred in hemodialysis patients in response to a $25 \%$ drop in hematocrit resulting from spontaneous hemorrhage. This response was much less marked than that reported for chronically anemic patients without renal failure. Such a hypothesis can therefore be reasonably excluded since the increase of circulating iEPO concentrations in 
our patients was much greater than that described by Walle et al., for a decrease in hematocrit that was either minor or absent. In our study, even patients who had received blood transfusions before and after PTx showed an increase of serum iEPO levels.

A decrease of plasma total phosphorus could be involved. Hyperphosphatemia, which is constantly observed in uremic patients with severe secondary hyperparathyroidism, leads to an increase in red cell glycolytic rate and a rise in adenosine triphosphate and 2,3-DPG. This rise leads to a decrease in the hemoglobin-oxygen affinity ('shift to the right') of the hemoglobin-oxygen dissociation curve [33], thus increasing tissue oxygenation. This may contribute to decreased EPO production and hence to anemia by reducing the hypoxic stimulus in the remaining renal cortex or the liver. Furthermore, in vitro studies have demonstrated that adenosine may modulate EPO release from renal cells [34] and in vivo studies have shown that the nonselective adenosine antagonist, theophylline, could prevent the polycythemia often observed after renal transplantation $[35,36]$. Conceivably, correction of hyperphosphatemia by PTx would have the opposite effect on red cell adenosine triphosphate and 2,3-DPG levels and thereby augment EPO production and $\mathrm{Hb}$ levels. In contrast, the absence of an increase in serum $\mathrm{EEPO}$ after PTx in the patients with primary hyperparathyroidism could be explained at least partially by the significant increase in plasma phosphorus and in 2,3-DPG levels after PTx.

The chronically elevated serum calcium concentrations during hyperparathyroidism could also affect EPO production. Recently, it has been shown that calcium antagonists such as verapamil enhance EPO production in response to hypoxia [37]. Furthermore, Nagakura et al. [38] have demonstrated that low extracellular calcium levels $(0.3 \mathrm{mmol} / \mathrm{l})$ in culture medium significantly increased EPO production by human renal carcinoma cells. Recently, Washio et al. [30] have also demonstrated a transient increase of serum iEPO immediately after PTX $(3-24 \mathrm{~h})$ in hemodialysis patients. They observed that it was associated with a concomitant reduction of ionized serum calcium. Hypothetically, the rapid decrease of plasma calcium concentration after PTx could lead to a similar enhancement.

Patients undergoing PTx usually receive a substitution therapy with vitamin $D$ derivatives and therefore the question arises as to whether this hormone could be responsible for the rise of serum iEPO. However, our observation that calcitriol treatment causes a decrease rather than an increase of serum $\mathrm{EEPO}$ in uremic patients makes such an explanation very unlikely.

Consequently, either a direct or indirect inhibitory effect of PTH on EPO production has to be considered. So far, the effect of PTH on EPO formation is unknown, and we can therefore only speculate about possible mechanisms.

A direct effect of PTH on EPO production is also conceivable via the following pathway. Experimental evidence indicates that the oxygen consumption of the proximal renal tubule is involved in the 'oxygen sensing' that adapts EPO production to the renal oxygen supply [39]. On the other hand, PTH has been shown to inhibit respiration and phosphorylation in kidney cortex mitochondria [40]. Moreover, it inhibits phosphate and bicarbonate reabsorption and the $\mathrm{Na}^{+} / \mathrm{H}^{+}$exchange mechanism in the proximal tıbule [41-45]. It is therefore imaginable that PTH decreases the oxygen consumption of the proximal tubule and thus leads to a decrease of EPO production since more oxygen is available. Compatible with this idea would be the observation that in our patients prior to PTx, serum EPO was inappropriately low in relation to the hemoglobin concentration whereas after PTx, serum EPO was in the range which is found in severely anemic patients with normal renal function [46]. Interestingly, the drastic reduction of circulating iPTH has also been demonstrated to lead to an increase of the plasma concentration of another polypeptide hormone, namely insulin, possibly via similar pathogenetic mechanisms [47-49].

On the other hand, it has been shown that high concentrations of intact PTH in vitro exert an inhibitory effect on erythropoiesis, leading to a decrease in burstforming-units erythroid and the colony-forming-units erythroid [14]. The increase in reticulocyte count in the absence of change of serum iEPO after PTx, observed in patients with primary hyperparathyroidism might suggest that erythroid progenitors of bone marrow become more sensitive to EPO action afi.: the reduction of plasma PTH.

It is also of note that a rapid, significant increase of platelet count was observed after PTx in group I patients. This could be an expression of increased EPO production or of some other thrombocytopoiesis-stimulating factor [50], possibly related to the correction of severe hyperparathyroidism, of the decrease of high PTH levels being deleterious for platelets. or of the surgical procedure alone.

Finally, the site of heavily increased EPO production after PTx in hemodialysis patients with terminal renal 
failure has not been clearly established in the present study. Even though none of these patients was anephric, the residual function of renal parenchyma was almost certainly severely depressed, if not absent in at least some of them. None of the patients conserved any rejected renal tissue from a previous renal allograft. Therefore, the liver has to be considered as an alternative source of acute EPO production in at least part of these patients [51, 52]. In keeping with this is the capacity of anephric patients to acutely induce EPO production when exposed to a marked hypoxic stimulus [53].

In conclusion, the mechanism through which PTx leads to a striking increase in serum iEPO in uremic patients remains unclear. Acute changes of circulating PTH as well as of extra- or intracellular calcium and phosphorus concentrations after the surgical correction of severe hyperparathyroidism all remain possible candidates. In contrast, the surgical procedure and the acute increase in plasma calcitriol induced by oral supplementation with active vitamin D derivatives do not appear to be involved. In patients with primary hyperparathyroidism, PTx led to an increase in blood reticulocytes, in the absence of a significant change of serum iEPO levels. This could indicate improved tissue sensitivity to the hormone. More study is clearly needed to better understand the present observations and their possible relevance for the relation between hyperparathyroidism and anemia.

\section{Acknowledgments}

The authors thank Dr. J.P. Juquel, AURA home dialysis center, Paris, Dr. J.P. Rechke, dialysis center. Melun, Dr. G. Turlin, dialysis center, Vichy, Dr. A. Moynot, AURA dialysis center. Paris, Mr. J.C. Souberbielle. Necker Hospital, Paris for the plasma parathyroid hormone measurements, and the nursing staff of the Nephrology Department, Necker Hospital, and the Surgical Department, Saint-Louis Hospital, Paris for valuable help in the study protocol.

\section{References}

1 Erslev A: Humoral regulation of red blood cell production. Blood 1953:8:349-357.

2 Myake T, Kung CKH, Goldwasser E: Purification of human erythropoietin. J Biol Chem 1977:252:5558-5564.

3 Lai PH, Everett R. Wang FF, Arakawa T. Goldwasser E: Structural characterization of human erythropoietin. J Biol Chem 1986:261:3116-3131.

4 Lacombe C. Da Silva J-L. Bruneval P. Fournier JG. Wendling F. Casadevall N, Camilleri JP. Bariety J, Varet B. Tambourin P:
Peritubular cells are the site of ervthropoietin synthesis in the murine hypoxic kidney. J Clin Invest 1988:81:620-623.

5 Koury ST. Bondurant MC. Koury MJ : Localisation of erythropoietin synthesizing cells in murine kidneys by in situ hybridization. Blood 1988:71:524-527.

6 Eckardt K-U. Mollmann M. Neumann R. Brunkhorst R. Burger H-U, Lonnemann G, Scholz H. Keusch G. Buchholz B. Frei U, Bauer C. Kurtz A: Erythropoietin in polycystic kidneys. J Clin Invest 1989:84:1160-1166.

7 Eckardt K-U. Bauer C: Ervthropoietin in health and disease. Eur J Clin Invest 1989:19:117-127.

8 Schuster SJ. Wilson JH. Erslev AJ, Caro J: Physiologic regulation and tissue localization of renal erythropoietin messenger RNA. Blood 1987: 70:316-318.

9 Eschbach JW: The anemia of chronic renal failure: Pathophysiology and the effects of recombinant erythropoietin. Kidney Int 1989:35:134-148.

10 Caro J. Erslev AJ: Erythropoietin assays and their use in the study of anemias. Contrib Nephrol 1988:66:54-62.

11 Winearls CG, Oliver DO. Pippard MJ. Reid C, Downing MR. Cotes PM: Effect of human erythropoietin derived from recombinant DNA on the anaemia of patients maintained by chronic haemodialysis. Lancet 1986:ii:1175-1177.

12 Zins B, Drüeke T, Zingraff J, Bererhi L. Kreis $H$, Naret $C$. Delons S, Castaigne JP. Peterlongo F, Casadevall N. Varet B Erythropoietin treatment in anaemic patients on haemodialysis. Lancet 1986:ii:1329.

13 Eschbach JW. Egrie JC. Downing MR. Browne JK. Adamson JW: Correction of anemia of end-stage renal disease (ESRD) with recombinant human erythropoietin: Results of a phase 1-II clinical trial. N Engl J Med 1987:316:73-78:

14 Meytes D, Bogin E, Ma (. Dukes PP. Massry SG: Effects of parathyroid hormone on erythropoiesis. I Clin Invest 1981: $67: 126.3-1269$.

15 Bogin E. Massry G, Levi J, Djaldeti M. Bristol G. Smith G Effect of parathyroid hormone on osmotic fragility of human erythrocytes. J Clin Invest 1982:69:1017-1025.

16 Coburn JW. Slatopolsky E: Vitamin D, parathyroid hormone and renal osteodystrophy: in Brenner BM. Rector FC Jr (eds) The Kidney. Philadelphia, Saunders, 1986, p 1657

17 Potasman I, Better OS: The role of secondary hyperparathyroidism in the anemia of chronic renal failure. Nephron 1983 33:229-231.

18 Falko JM, Guy JT, Smith RE, Mazzaferri EL: Primary hyperparathyroidism and anemia. Arch Intern Med 1976:136:887-889.

19 Boxer M, Ellman L. Geller R, Wang C: Anemia in primary hyperparathyroidism. Arch Intern Med 1977:137:558-593.

20 Zingraff J, Drüeke T, Marie P. Man NK. Jungers P. Bordier P: Anemia and secondary hyperparathyroidism. Arch Intern Med $1978: 138: 1650-1652$

21 Barbour GL: Effect of parathyroidectomy on anemia in chronic renal failure. Arch Intern Med 1979:139:889-891.

22 Shasha SM. Better OS. Winaver J, Chaimovitz C. Barzilai A, Erlik D: Improvement in the anemia of hemodialyzed patients following subtotal parathyroidectomy. Evidence for the role of secondary hyperparathyroidism in the etiology of the anemia of chronic renal failure. Isr J Med Sci 1978:14:328-332.

23 Eckardt K-U, Kurtz A. Hirth P. Scigalla P. Wieczorek L. Bauer $C$ : Evaluation of the stability of human ervthropoietin in 
samples for radioimmunoassay. Klin Wochenschr 1988:66: 241-245.

24 McGonigle RJS, Wallin JD, Shadduck RK, Fisher JW: Erythropoietin deficiency and inhibition of erythropoiesis in renal insufficiency. Kidney Int 1984:25:437-444.

25 Chandra M. Clemons G, McVicar MI: Relation of serum erythropoietin levels to renal excretory function: Evidence for lowered set point for erythropoietin production in chronic renal failure. J Pediatr 1988:113:1015-1021.

26 Walle AJ, Wong GY. Clemos GK, Garcia JF. Niedermayer W: Erythropoietin-hematocrit feedback circuit in the anemia of end-stage renal disease. Kidney Int 1987:31:1205-1209.

27 Stanbury SW, Lumb GA: Parathyroid function in chronic renal failure: A statistical survey of plasma biochemistry in azotemic renal osteodystrophy. Q J Med 1966:35:1-23.

28 Caro J, Brown S, Miller O, Murray T, Erslev AJ: Erythropoietin levels in uremic nephric and anephric patients. J Lab Clin Med 1979:93:449-458.

29 McGonigle RJS, Wallin JD, Husserl F, Deftos LJ, Rice JC, O'Neill WJ, Fisher JW: Potential role of parathyroid hormone as an inhibitor of erythropoiesis in the anemia of renal failure. $J$ Lab Clin Med 1984;104:1016-1026.

30 Washio M, Iseki K, Oh Y, Nakamoto M, Fujimi S. Onoyama K, Fujishima M: Transient increase of serum erythropoietin (EPO) after subtotal parathyroidectomy (PTX) in patients (PTS) with chronic hemodialysis (HD). Kidney Int 1990:37:285.

31 Besarab A. Caro J, Jarell BE. Francos G, Erslev AJ: Dynamics of erythropoiesis following renal transplantation. Kidney Int 1987:32:526-536.

32 Eckardt K-U, Frei U, Kliem V. Bauer C, Koch KM, Kurtz A: Role of excretory graft function for erythropoietin formation after renal transplantation. Eur J Clin Invest, in press.

33 Lichtman MA. Miller DR, Abel V, Kearney E, Lockwood C: Erylhrocyte glycolysis, 2,3-diphosphoglycerate and adenosine triphosphate concentration in uremic subjects: Relationship to extracellular phosphate concentration. I Lab Clin Med 1970: $76: 267-279$.

34 Ueno M. Brookins J, Beckman B, Fisher JW: Al and A2 adenosine receptor regulation of erythropoietin production. Life Sci 1988:43:229-237.

35 Sauter E, Dupre J, Wincett R, Gaber O, Fisher J. Bakris GL: A role for adenosine in post renal transplant polycytemia. Kidney Int 1990:37:612

36 Bakris GL, Sauter E, Hussey JL, Fisher J, Gaber O, Wincett R: Effects of theophylline on erythropoietin production in normal subjects and in patients with erythrocytosis after renal transplantation. N Engl J Med 1990:323:86-90.

37 McConigle RJS, Brookins J, Pegram BL, Fischer JW: Enhanced erythropoietin production by calcium entry blockers in rats exposed to hypoxia. J Pharmacol Exp Ther 1987:241:428-432.

38 Nagakura K, Ueno M, Brookins J, Beckman BS, Fisher JW: Effects of low calcium levels on erythropoietin production by human renal carcinoma cells in culture. Am J Physiol 1987; 253: $(797-C 801$.

39 Eckardt K-U. Kurtz A, Bauer C: Regulation of erythropoietin production is related to proximal tubular function. Am J Physiol 1989:256: F942-F947.
40 Cohn DV, Smaich AF, Levy R: The inhibition of respiration and phosphorylation in kidney mitochondria by parathyroid hormone administered in vivo. J Biol Chem 1966:241:889-894.

41 Know FG. Haramati $A$ : Renal regulation of phosphate excretion: in Seldin DW, Giebisch G (eds): The Kidney: Physiology and Pathophysiology. New York, Raven, 1985, pp 1381-1396.

42 Bank N, Aynedjian HS: A micropuncture study of the effect of parathyroid hormone on renal bicarbonate reabsorption. J Clin Invest 1976:58:336-344.

43 McKinney TD, Myers P: Bicarbonate transport by proximal tubules: effect of parathyroid hormone and dibutyryl cyclic AMP. Am J Physiol 1980:238: F166-F174.

44 Hammerman MR, Klahr S, Cohn DE: Renal failure, metabolic acidosis, and parathyroidectomy in the dog increase $\mathrm{Na}^{+}-\mathrm{H}^{+}$ exchange in isolated renal brush border membrane vesicles: in Forte J, Rector F (eds): Hydrogen Ion Transport in Epithelia. New York, Wiley, 1983, pp 139-146.

45 Massry SG, Kurokawa K, Arieff AI, Ben-Isaac C: Metabolic acidosis of hyperparathyroidism. Arch Intern Med 1974:134: 385-387.

46 Erslev AJ, Wilson J. Caro J: Erythropoietin titers in anemic, non-uremic patients. J Lab Clin Med 1987:109:429-433.

47 Akmal M. Massry SG, Goldstein DA, Fanti P, Weisz A, DeFronzo RA: Role of parathyroid hormone in the glucose intolerance of chronic renal failure. J Clin Invest 1985:75:1037-1044.

48 Mak RHK, Bettinelli A, Turner C. Haycock GB, Chantler C: The influence of hyperparathyroidism on glucose metabolism in uremia. J Clin Endocrinol Metab 1985;60:229-233.

49 Mak RHK: Insulin secretion in uremia: Effect of parathyroid hormone and vitamin D metabolites. Kidney Int 1989:36:S227-S-230.

50 Bruno E, Miller M. Hoffman R: Interacting cytokines regulate in vitro human megakaryocytopoiesis. Blood 1989:73:671-677.

51 Fried $W$ : The liver as a source of extrarenal erythropoietin production. Blood 1972:40:671-677.

52 Brown S, Caro J, Erslev AJ, Murray TG: Spontaneous increase in erythropoietin and hematocrit value associated with transient liver enzyme abnormalities in an anephric patient undergoing hemodialysis. Am J Med 1980;68:280-284.

53 DeGowin RL, Lavender AR, Forland M, Charleston D, Gottschalk A: Erythropoiesis and erythropoietin in patients with chronic renal failure treated with hemodialysis and testosterone. Ann Intern Med 1970:72:913-918.

Accepted: January 18, 1991

Pablo Ureña, MD

Département de Néphrologie

INSERM Unité 90

Hôpital Necker-Enfants Malades

161. rue de Sèvres

F-75743 Paris Cedex 15 (France) 